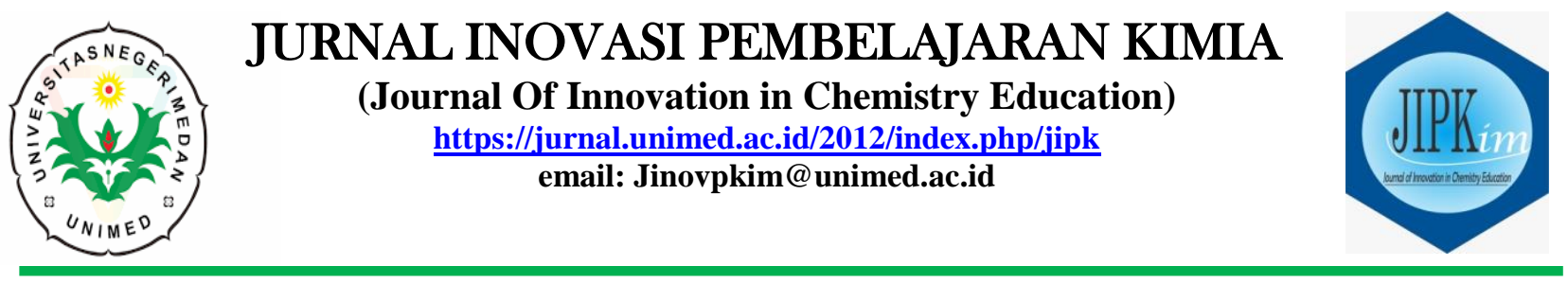

\title{
Korelasi Keterampilan Proses Sains dan Keterampilan Metakognitif Terhadap Hasil Belajar Kimia Pada Materi Titrasi Asam Basa di SMA
}

\author{
Widia Arta Siregar ${ }^{\mathrm{a}, *}$, Pasar Maulim Silitonga ${ }^{\mathrm{a}}$ \\ ${ }^{a}$ Program Studi Pendidikan Kimia, Universitas Negeri Medan, Medan \\ *Alamat Korespondensi: silitonga@gmail.com
}

\begin{abstract}
:
This study aims to determine whether there is a linear and significant relationship between science process skills and student chemistry learning outcomes; metacognitive skills with student chemistry learning outcomes; science process skills and metacognitive skills with student chemistry learning outcomes. The population in this study were all students of class XI Mathematics and Senior High School Angkasa 1 Lanud Medan consisting of 2 classes. The research sample is one class taken by purposive technique. Based on the results of data analysis, it is concluded that there is a linear and significant relationship between science process skills and chemistry learning outcomes with a correlation value of 0.621 (high correlation) and the contribution of science process skills by 38.56\%. In addition there is also a linear and significant relationship between metacognitive skills on student chemistry learning outcomes with a correlation value of 0.5 (enough correlation) and the contribution of metacognitive skills by $25 \%$. And there is also a linear and significant relationship between science process skills and metacognitive skills on student chemistry learning outcomes with a correlation value of 0.809 (high correlation) and a contribution of $65.44 \%$.
\end{abstract}

Keywords:

Science Process Skills, Metacognitive Skills, Learning Outcomes, Acid Base Titration

\section{PENDAHULUAN}

Pada saat ini sebagai panduan pembelajaran adalah penerapan kurikulum 2013. Penerapan kurikulum 2013 ini bertujuan untuk meminimalisir peran guru atau sekolah dan menambah peran siswa sebagai pihak yang aktif dalam kegiatan pembelajaran. Untuk itu, mereka dilibatkan dalam proses pembelajaran melalui pengamatan, menanya, mencoba, menalar, dan mengkomunikasikan. Dalam kurikulum 2013, kompetensi lulusan program pendidikan harus mencakup tiga kompetensi yaitu sikap, pengetahuan, dan keterampilan (Anggraini, 2016).
Materi Titrasi Asam basa adalah salah satu materi yang sulit dipahami oleh siswa jika hanya diberikan secara teori saja, sehingga harus diimbangi dengan kegiatan praktikum. Materi titrasi menuntut siswa untuk menggunakan alat titrasi dengan benar, mengamati volume titrasi, melakukan percobaan sesuai dengan prosedur, memprediksi seberapa kadar suatu sampel dengan cara titrasi dan membuat kesimpulan dengan menggrafikkan kurva titrasi (Ariadi, 2015).

Pada pembelajaran kimia tidak hanya menuntut penguasaan pengetahuan yang berupa fakta, konsep dan prinsip melainkan proses penemuannya. Proses tersebut didapat 
dari pengalaman melalui kegiatan percobaan atau praktikum. Praktikum sudah menjadi bagian yang penting di dalam ilmu sains dan kegiatan praktikum dapat member kesempatan bagi peserta didik untuk mencari tahu sendiri apa yang dibutuhkannya dan dapat mengeksplorasi kreatifitasnya. Untuk memperoleh proses penemuan dalam pembelajaran kimia dibutuhkan suatu keterampilan tertentu yang disebut keterampilan proses sains (Dewi, 2008). Pembelajaran kimia diarahkan pada pendekatan saintifik dimana keterampilan proses sains dilakukan melalui percobaan untuk membuktikan sebuah kebenaran sehingga berdasarkan pengalaman secara langsung membentuk konsep, prinsip, serta teori yang melandasinya (Magdalena, dkk, 2014).

Keterampilan Proses Sains siswa penting untuk dikembangkan dikarenakan siswa tidak hanya mempelajari apa yang sudah ada tetapi siswa juga belajar bagaimana memperoleh pengetahuan tersebut. Selain itu dengan keterampilan proses sains, siswa dituntut untuk lebih aktif dan kreatif dalam memecahkan masalah dan menghubungkan pelajaran dengan hal-hal yang terjadi dalam kehidupan sehari-hari mereka (Suardani, dkk, 2014). Hasil Penelitian Dewi (2016), menunjukkan bahwa hubungan keterlaksanaan model SSCS dengan kemampuan keterampilan proses sains diperoleh $r_{x y}=0,756$ dengan tingkat hubungan kuat dan uji signifikansi dilakukan dengan uji $t$ dengan diperoleh $t_{\text {hitung }}>t_{\text {tabel }}$ $(6,65>2,021)$ dengan $\mathrm{dk}=33$ dan $\alpha=0,05$ dengan tingkat signifikan.

Rahman, dkk (2010), mengungkapkan bahwa Keterampilan Metakognitif berhubungan dengan pencapaian akademik siswa, yakni keterampilan metakognitif mempunyai hubungan positif dengan pencapaian akademik siswa serta berhubungan juga dengan pencapaian pembelajaran. Berdasarkan hal tersebut dapat diketahui bahwa keterampilan metakognitif siswa sangat menentukan hasil belajar siswa, karena dengan keterampilan metakognitif, siswa akan mampu merencanakan, memantau, dan menilai proses yang akan, sedang, dan telah dilakukan didalam pembelajaran. Hasil penelitian Suyanti (2016), menunjukkan bahwa hubungan antara Keterampilan metakognif terhadap penguasaan konsep kimia siswa memiliki nilai $r=0,699$, yang menunjukkan bahwa terdapat hubungan positif, kuat, dan signifikan antar variabel tersebut.

Berdasarkan hasil wawancara yang telah dilakukan peneliti dengan guru SMAS Angkasa 1 Lanud Medan mengatakan meskipun SMAS Angkasa 1 Lanud Medan telah menerapkan kurikulum 2013 namun, dalam proses pembelajaran masih banyak siswa yang cenderung pasif, hanya menerima materi yang diajarkan, tanpa mau menelaah lebih dalam dan berkelanjutan dan kurangnya inisiatif siswa bertanya kepada guru dan masih banyak siswa yang kurang terampil dalam melakukan kegiatan praktikum. Hasil wawancara dengan beberapa siswa SMAS Angkasa 1 Lanud Medan menunjukkan bahwa mereka sering tidak merencanakan waktu yang akan mereka gunakan untuk mengerjakan tugas yang diberikan oleh guru, sehingga terkadang mereka kekurangan waktu dalam menyelesaikan tugas yang diberikan, dari hasil wawancara peneliti diperoleh bahwa keterampilan proses sains dan keterampilan metakognitif siswa SMAS Angkasa 1 Lanud Medan masih minim.

Penelitian yang dilakukan Sari dkk (2017) mengungkapkan bahwa terdapat kontribusi keterampilan proses sains terhadap hasil belajar siswa dimana pada aspek mengamati sebesar 82,03 dengan kategori sangat baik, pada aspek menggolongkan diperoleh nilai sebesar 78,91 dengan kategori baik, pada aspek meramalkan diperoleh 90,63 dengan kategori sangat baik, pada aspek menerapkan diperoleh nilai sebesar 76,57 dengan kategori baik, dan pada aspek mengkomunikasikan memperoleh nilai sebesar 82,03 dengan kategori baik.

Penelitian terdahulu yang dilakukan Nuryana dkk (2012), menunjukkan bahwa terdapat hubungan yang signifikan antara keterampilan metakognisi dengan hasil belajar siswa dimana dilihat menggunakan 
angket yang meliputi tahap planning skill,monitoring skill, evaluation skill dan diperoleh nilai hubungan antara planning skill dengan hasil belajar siswa diperoleh nilai $r$ sebesar 0,701 dengan interpretasi hubungan cukup, sedangkan hubungan antara monitoring skill dengan hasil belajar siswa diperoleh nilai $\mathrm{r}$ sebesar 0,8666 dengan interpretasi hubungan tinggi, dan hubungan antara evaluation skill dengan hasil belajar siswa diperoleh nilai $r$ sebesar 0,844 dengan interpretasi hubungan tinggi.

Uji signifikansi korelasi dilakukan dengan membandingkan nilai $r$ yang diperoleh ( $r$-hit) dengan $r$ tabel pada tingkat signifikansi tertentu, dengan kriteria : jika $r$ hit $\geq$ r-tabel maka Ho ditolak yang berarti : ada korelasi positif/negatif yang signifikan antara variabel $\mathrm{X}$ dengan variabel $\mathrm{Y}$ (Silitonga, 2014). Koefisien korelasi akan bernilai satu bila terdapat hubungan linier yang positif dan bernilai -1 bila terdapat hubungan linier yang negatif. Bila nilai korelasi diantara -1 dan +1 , hal ini menunjukkan tingkat dependensi linier antara dua variabel (Sitorus dkk, 2014)

\section{METODE}

Penelitian ini telah dilaksanakan di SMAS Angkasa 1 Lanud Medan yang berlokasi di Jalan Polonia No.99 Medan. Waktu penelitian dilaksanakan pada 23 Maret - 25 April 2019 Tahun Ajaran 2018/2019. Populasi dalam penelitian ini adalah seluruh siswa kelas XI MIPA SMAS Angkasa 1 Lanud Medan yang berlokasi di Jalan Polonia No.99 Medan Tahun Ajaran 2018/2019 yang terdiri dari 2 kelas. Sampel dalam penelitian ini yaitu XI IPA-2 yang diambil secara purposive sampling.

Penelitian ini merupakan penelitian kuantitaif dengan metode analisis menggunakan uji regresi linier ganda dengan dua variabel bebas yaitu Keterampilan Proses Sains (X1), Keterampilan Metakognitif (X2) dan satu variabel terikat yaitu hasil belajar siswa pada materi Titrasi Asam Basa (Y).

Bentuk hubungan (paradigma) penelitian dengan judul "Korelasi Keterampilan Proses Sains dan Keterampilan
Metakognitif Terhadap Hasil Belajar Kimia Siswa pada pokok Bahasan Titrasi Asam Basa di Kelas XI SMA” yaitu :

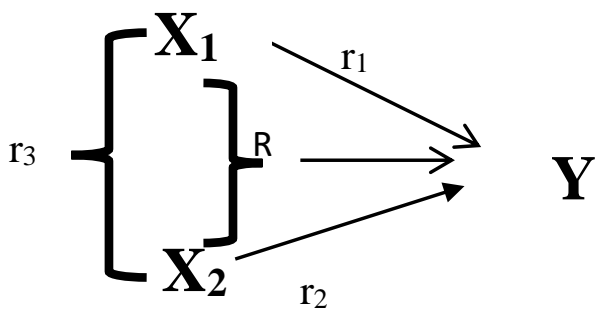

1. Untuk mencari hubungan antara dua variabel, satu variabel bebas $\left(\mathrm{X}_{1}\right.$ atau $\left.\mathrm{X}_{2}\right)$ dengan satu variabel terikat (Y), digunakan teknik analisis persamaan regresi linier sederhana dengan persamaan sebagai berikut : $\mathrm{Y}=\mathrm{a}+\mathrm{bX}$

2. Untuk mencari hubungan ketiga variabel digunakan teknik analisis regresi ganda naik turun harga $\mathrm{Y}$ dapat diprediksi melalui persamaan regresi $\mathrm{Y}$ atas $\mathrm{X}$, dengan persamaan $\mathrm{Y}=\mathrm{a}+\mathrm{b}_{1} \mathrm{X}_{1}+\mathrm{b}_{2} \mathrm{X}_{2}$

Uji hipotesis dilakukan dengan menggunakan teknik, yaitu :

Uji Linearitas regresi yang dilakukan dengan analisis varians (sidik ragam) untuk mengetahui apakah ada hubungan yang signifikan antara keterampilan proses sains dengan hasil belajar kimia siswa.

$$
\hat{\mathbf{Y}}=\mathbf{a}+\mathbf{b X}
$$

Analisis regresi linier ganda dengan naik turun harga $\mathrm{Y}$ dapat diprediksi melalui persamaan regresi $\mathrm{Y}$ atas $\mathrm{X}$, dengan persamaan $Y=a+b_{1} X_{1}+b_{2} X_{2}$

Analisis korelasi digunakan untuk mengukur seberapa erat hubungan antara dua variabel atau lebih. Untuk menghitung korelasi ganda, maka harus dihitung terlebih dahulu korelasi sederhananya melalui korelasi Product Moment dari Pearson.

\section{HASIL DAN PEMBAHASAN}

Setelah diperoleh data dari penelitian, maka dilakukan uji hipotesis dengan menggunakan uji statistik yaitu uji-t dua pihak dengan tujuan untuk mengetahui apakah hipotesis dalam penelitian ini diterima atau ditolak. Kriteria pengujian Fhitung > Ftabel maka Hipotesis alternatif diterima dan hipotesis nihil ditolak. 


\section{Pengujian Hipotesis 1}

Uji Linearitas Regresi digunakan untuk menguji apakah ada hubungan yang linear (hubungan sebab akibat) yang signifikan antara keterampilan proses sains $\left(\mathrm{X}_{1}\right)$ dengan hasil belajar kimia $(\mathrm{Y})$.

Uji ini dilakukan dengan membandingkan nilai $F_{\text {hitung }}$ dengan $F_{\text {tabel }}$ dengan kriteria jika $F_{\text {hitung }} \geq \mathrm{F}_{\text {tabel }}$ berarti Ho ditolak dan $\mathrm{Ha}$ diterima. Data hasil perhitungan uji linearitas regresi dapat dilihat Tabel 1 dibawah ini :

Tabel 1. Daftar Sidik Ragam

\begin{tabular}{llllll}
\hline $\begin{array}{l}\text { Sumber } \\
\text { Keragaman }\end{array}$ & Db & JK & KT & Fhit & F(0.05)(1)(28) \\
\hline Regresi ( R ) & 1 & 633,57 & 633,57 & 9,33 & 4,20 \\
Sisaan ( s ) & 28 & 1900,6 & 67,87 & & \\
Total & $\mathbf{2 9}$ & $\mathbf{2 5 3 4 , 1 7}$ & & & \\
& & & & & \\
\hline
\end{tabular}
terdapat hubungan antara keterampilan proses sains dengan hasil belajar kimia siswa diperoleh $\quad F_{\text {hitung }}=24,68$ dan $F_{\text {tabel }}$ $(0,05)(1)(28)$ adalah sebesar 4,20. Kriteria pengujian hipotesis tersebut menunjukkan bahwa harga $F_{\text {hitung }}>F_{\text {tabel }}$, sehingga $\mathrm{Ha}$ diterima dan Ho ditolak yaitu ada hubungan yang linear dan signifikan antara keterampilan proses sains dengan hasil belajar kimia siswa.

basa.

\section{a. Analisis Korelasi}

Untuk mengetahui apakah ada korelasi positif antara keterampilan proses sains dengan hasil belajar kimia atau seberapa erat hubungan antara kedua variabel dapat dilakukan analisis korelasi dengan koefisien korelasi berkisar $-1<\mathrm{r}\rangle+1$. Dari perhitungan diperoleh koefisien korelasi

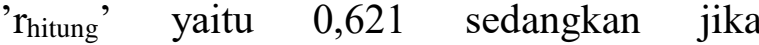
dikonsultasikan ke tabel $\mathrm{r}$ product moment diperoleh $r_{\text {tabel }}=0,334$. Jadi $r_{\text {hitung }}>r_{\text {tabel }}$ artinya ada korelasi yang positif antara keterampilan proses sains terhadap hasil belajar kimia.

\section{b. Analisis Koefisien Determinasi}

Untuk mempererat penjelasan hubungan keterampilan proses sains dengan hasil belajar kimia siswa, maka dapat dicari seberapa besar kontribusi keterampilan proses sains terhadap hasil belajar kimia dengan uji koefisien determinasi (CD). Berdasarkan perhitungan diperoleh kontribusi keterampilan proses sains sebesar $38,56 \%$

\section{Pengujian Hipotesis 2}

Uji Linearitas Regresi digunakan untuk menguji apakah ada hubungan yang linear (hubungan sebab akibat) yang signifikan antara keterampilan metakognitif $\left(\mathrm{X}_{2}\right)$ dengan hasil belajar kimia siswa $(\mathrm{Y})$. Uji ini dilakukan dengan membandingkan nilai $F_{\text {hitung }}$ dengan $F_{\text {tabel }}$ dengan kriteria jika $F_{\text {hitung }} \geq \mathrm{F}_{\text {tabel }}$ berarti Ho ditolak dan $\mathrm{Ha}$ diterima. Data hasil perhitungan uji linearitas regresi dapat dilihat Tabel 2 dibawah ini :

Tabel 2. Daftar sidik ragam

\begin{tabular}{llllll}
\hline $\begin{array}{l}\text { Sumber } \\
\text { Keragaman }\end{array}$ & Db & JK & KT & Fhit & $\mathrm{F}(0.05)(1)(28)$ \\
\hline Regresi ( R ) & 1 & 633,57 & 633,57 & 9,33 & 4,20 \\
Sisaan ( s ) & 28 & 1900,6 & 67,87 & & \\
Total & $\mathbf{2 9}$ & $\mathbf{2 5 3 4 , 1 7}$ & & & \\
& & & &
\end{tabular}

Dengan demikian diperoleh $\mathrm{F}_{\text {hitung }}=$ 9,33 sedangkan $F_{\text {tabel }}(0,05)(1)(28)$ adalah sebesar 4,20. Karena $F_{\text {hitung }}>F_{\text {tabel }}$ maka Ho ditolak yang artinya Ha diterima. Artinya ada hubungan yang linear dan signifikan antara keterampilan metakognitif dengan hasil belajar kimia siswa pada pokok bahasan titrasi asam basa.

a. Analisis Korelasi

Dari perhitungan diperoleh koefisien

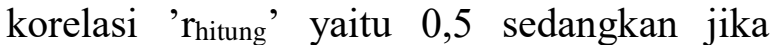
dikonsultasikan ke tabel $\mathrm{r}$ product moment diperoleh $\quad r_{\text {tabel }}=0,334$. Jadi $r_{\text {hitung }}>r_{\text {tabel }}$ artinya ada korelasi yang positif antara keterampilan metakognitif terhadap hasil belajar kimia.

\section{b. Analisis Koefisien Determinasi}

Untuk mempererat penjelasan hubungan keterampilan proses sains dengan hasil belajar kimia siswa, maka dapat dicari seberapa besar kontribusi keterampilan proses sains terhadap hasil belajar kimia dengan uji koefisien determinasi (CD). Berdasarkan perhitungan diperoleh kontribusi keterampilan proses sains sebesar $25 \%$. 


\section{Pengujian Hipotesis 3}

Uji hipotesis III berupa uji regresi linear ganda yang dilakukan untuk menguji apakah ada hubungan keterampilan proses sains $\left(\mathrm{X}_{1}\right)$ dan keterampilan metakognitif $\left(\mathrm{X}_{2}\right)$ dengan hasil belajar kimia $(\mathrm{Y})$.

\section{a. Analisis Korelasi}

Sebelum mendapatkan nilai Fhitung, terlebih dahulu dicari korelasi antara keterampilan proses sains $\left(\mathrm{X}_{1}\right)$ dengan keterampilan metakognitif $\left(\mathrm{X}_{2}\right)$. Berdasarkan perhitungan yang sudah dilakukan diperoleh nilai $r_{. x 1} x_{2}=0,57$. Setelah nilai $r_{. x 1} x_{2}$ diperoleh, maka nilai korelasi untuk ketiga variabel dapat dicari yaitu sebesar 0,809 .

\section{b. Uji Signifikansi}

Pengujian signifikansi terhadap koefisien korelasi ganda dilakukan dengan membandingkan nilai $\mathrm{F}$ yang diperoleh ( $F_{\text {hitung }}$ ) dengan $F_{\text {tabel }}$ pada tingkat signifikansi tertentu, dengan kriteria : jika $F_{h i t} \geq F_{t}$ abel maka Ho ditolak. Dengan demikian diperoleh nilai $F_{\text {hit }}=25,57$, sedangkan $F_{\text {tabel }}$ pada $\alpha=$ 0,05 (dk pembilang 2 dan $\mathrm{dk}$ penyebut 27) diperoleh $\mathrm{F}_{\text {tabel }}=3,35$. Karena $\mathrm{F}_{\text {hit }} \geq \mathrm{F}_{\text {tabel }}$ maka Ho ditolak (Ha diterima). Berarti ada hubungan yang signifikan antara keterampilan proses sains dan keterampilan metakognitif dengan hasil belajar kimia siswa.

\section{c. Koefisien Determinasi}

Untuk menghitung besar kecilnya hubungan keterampilan proses sains dan keterampilan metakognitif dengan hasil belajar kimia, maka dapat dicari dengan menggunakan rumus koefisien determinasi (CD) sehingga diperoleh koefisien determinasinya sebesar $65,44 \%$. Jadi dapat dilihat bahwa hubungan keterampilan proses sains dan keterampilan metakognitif terhadap hasil belajar kimia itu cukup besar.

\section{d.Persamaan Regresi Linear Ganda}

Pada penelitian ini diperoleh persamaan regresi ganda menggambarkan hubungan antara kedua variabel $\mathrm{X}_{1}$ dan $\mathrm{X}_{2}$ dengan hasil belajar kimia yaitu :

$$
\mathrm{Y}=107,842+0,3726 \mathrm{X}_{1}+\mathbf{0 , 0 9 1 6} \mathrm{X}_{2}
$$

\section{DAFTAR PUSTAKA}

Anggraini, R., Haryono., dan Agustina, W., (2016), Penerapan Model Pembelajaran Search, Solve, Create and Share (SSCS) Untuk Meningkatkan Kemampuan Analisis dan Prestasi Belajar pada Materi Pokok Kelarutan dan Hasil Kali Kelarutan Siswa Kelas XI MIA 3 Semester Genap SMA Batik 2 Surakarta Tahun Pelajaran 2015/2016, Jurnal Pendidikan Kimia (JPK), 5(4) : 1-7.

Anggraini, W. I., Djudin, T., dan Maria, H. T., (2016), Kontribusi Keterampilan Proses Sains Siswa Terhadap Penguasaan Konsep Siswa, Jurnal Pendidikan dan Pembelajaran, 5(06) : 16-24

Ariadi, H., Hairida., dan Rasmawan, Rahmat., (2015), Keterampilan Kerja Ilmiah Pada Materi Titrasi Asam Basa Menggunakan Model Pembelajaran Inkuiri Terbimbing, Jurnal Pendidikan Kimia (JPK), 1(2) : 1-16.

Coutinho, S.A., (2007), The Relationship Between Goals, Metacognition, and Academic Succes, Educate Journal, 7(1): 39-47.

Desmita., (2010), Psikologi Perkembangan Peserta Didik, PT. Remaja Rosda Karya, Bandung.

Devi, P.K., (2010), Keterampilan Proses Dalam Pembelajaran IPA, PPPPTK, Jakarta.

Dewi, F., Afrida., dan Triwahyudi, S., (2016), Analisis Keterlaksanaan Model Pembelajaran search, solve, create and share (SSCS) dan pengaruhnya terhadap keterampilan proses sains siswa pada materi bentuk molekul kelas $\mathrm{X}$ MIA SMAN 11 Kota Jambi, J. Indo. Soc. Integ. Chem, 8(2) : 1-9

Dewi, S., (2008), Keterampilan Proses Sains, Tinta Emas Publishing, Bandung.

Dimyati., dan Mudjono., (2013), Belajar dan

Pembelajaran, Rineka Cipta, Jakarta. 
Erkol, S., dan Ugulu, I., (2014), Examining Biology Teachers Candidates Scientific Proses Skill Levels and Comparing These Levels in Terms of Various Variables, Procedia Social and Behavioral Sciences, 116 : 4742-4747

Gultepe, N., and Kilic, Z., (2015), Effect of Scientific Argumenation on the Development of Scientific process Skills in the Context of Teaching Chemistry, Journal of Environmental \& Science Education, 10 (1) : 112

Iin, Y., dan Sugiarto, B., (2012), Korelasi antara Keterampilan Metakognitif dengan Hasil Belajar Siswa di SMAN 1 Dawarblandong Mojokerto, Unesa Journal of Chemical Education, 1(2): 78-83.

In'am, A., (2009), Peningkatan Kualitas Pembelajaran melalui Lesson Study Berbasis Metakognisi, Jurnal Salam,12(1):125-135.

Magdalena, O., Mulyani, S., dan Susanti, E., (2014), Pengaruh Model Pembelajaran Problem Based Learning Dan Inquiry Terhadap Prestasi Belajar Siswa Ditinjau Dari Kreativitas Verbal Pada Materi Hukum Dasar Kimia Kelas X SMAN 1 Boyolali Tahun Pelajaran 2013/2014, Jurnal Pendidikan Kimia, 3(4) : 162-169.

Malahayati, E. N., Corebima, A. D., dan Zubaidah, S., (2015), Hubungan Keterampilan Metakognitif Dan Kemampuan Berpikir Kritis Dengan Hasil Belajar Biologi Siswa Sma Dalam Pembelajaran Problem Based Learning., Jurnal Pendidikan Sains, 3(4): 178-186.

Milfayetty, S., Yus Anita., Nuraini., Rahmulyani., dan Hutasuhut, Edison., (2018), Psikologi Pendidikan, Pascasarja Unimed, Medan.

Miranda, Y., (2010), Dampak Pembelajaran Metakognitif dengan Strategi
Kooperatif Terhadap Kemampuan Metakognisi Siswa dalam Mata Pelajaran Biologi di SMAN Palangka Raya, Jurnal Penelitian Kependidikan, 20(2) : 233-267.

Mulbar, Usman., (2008), Metakognisi Siswa dalam Menyelesaikan Masalah Matematika, Jurnal Pendidikan, 1(3) : 65-79.

Nur, M., (2004), Teori-Teori Perkembangan Metakognitif Edisi 2, Universitas Negeri Surabaya, Surabaya.

Nuryana, E., dan Sugiarto, B., (2012), Hubungan Keterampilan Metakognisi dengan Hasil Belajar Siswa pada Materi Reaksi Reduksi Oksidasi (Redoks) kelas X-1 SMA Negeri 3 Sidoarjo, Unesa Journal of Chemical Education, 1(1) : 83-91.

Rahayu, E., Susanto, H., dan Yulianti, D., (2011), Pembelajaran Sains dengan Pendekatan Keterampilan Proses untuk Meningkatkan Hasil Belajar dan Kemampuan Berpikir Kreatif Siswa, Jurnal Pendidikan Fisika Indonesia, 7(2) : 106-110.

Rahman, U. F., Jumani, B. N.,Chaudry, A. M., Chisti, U. S., and Abbasi. F., (2010), Impact Metacognitiv awareness on performance of students in chemistry, Cotemparry Issues in Education Research, 3(1) : 79-88

Rahman, S., dan Philips, J.A., (2006), Hubungan antara Kesadaran Metakognisi, Motivasi dan Pencapaian Akademik Pelajar Universiti, Jurnal Pendidikan,3 (1):21-39.

Rusmiyati, A., dan Yulianto, A., (2014), Peningkatan Keterampilan Proses Sains dengan Menerapkan Model Problem Based Instruction, Jurnal Pendidkan Fisika Indonesia, 5(1) : 75-78

Sari, I. N., Azwar, I., dan Riska., (2017), Kontribusi Keterampilan Proses Sains Siswa Terhadap Hasil Belajar Siswa Pada Materi Wujud Zat dan Perubahannya, Jurnal Pendidikan 
Informatika dan Sains,6(2) : 257266.

Semiawan, Conny., (1985), Pendekatan Keterampilan Proses, Bagaimana Mengaktifkan Siswa dalam Belajar, Gramedia, Jakarta.

Silitonga, P.M ., (2014), Statistik Teori dan Aplikasi dalam Penelitian, FMIPA UNIMED, Medan.

Sitorus, T. B., Napitupulu, F. H., dan Ambarita, H., (2014), Korelasi temperatur udara dan intensitas radiasi matahari terhadap performansi mesin pendingin siklus adsorpsi tenaga matahari, 1(1) : 817.

Suardani, N. N., Swasta, I. B. J., Widayanti, N. L., (2014), Pengaruh Model Pembelajaran Berbasis Masalah Terhadap Kemampuan Pemecahan Masalah dan Keterampilan Proses Sains Siswa, Jurnal Pendidikan dan Pembelajaran IPA Indonesia, 4(1) : 1-9

Sugiyono., (2011), Statistika Untuk Penelitian, Alfabeta, Bandung.

Sutresna, N., Sholehuedin, D., dan Herlina, T., (2016), Aktif dan Kreatif Belajar Kimia 2 untuk SMA/MA Kelas XI, Grafindo Media Pratam, Bandung.

Suyanti., Sunyono., Efkar, T., (2016), Hubungan Efikasi Diri dan Kemampuan metakognisi dengan penguasaan konsep kimia menggunakan model simayang, Jurnal Pendidikan dan Pembelajaran Kimia, 5(3) : (52-64).

Tawil, M., dan Liliasari., (2014), Keterampilan-keterampilan sains dan Implementasinya dalam pembelajaran IPA, Universitas Negeri Malang, Malang.

Wahyudienie, M, B., Sunyono., dan Efkar, T., (2016), Hubungan Antara Metakognisi Dan Keterampilan Proses Sains Dengan Hasil Belajar Dalam Pembelajaran Asam Basa Menggunakan Model Simayang, Jurnal Pendidikan dan Pembelajaran Kimia, 5(4) : (65-77).
Wahyudi, L. E., dan Supardi, Z. A. I., (2013), Penerapan Model Pembelajaran Inkuiri Terbimbing Pada Pokok Bahasan Kalor Untuk Melatihkan Keterampilan Proses Sains Terhadap Hasil Belajar di SMAN 1 Sumenep, Jurnal Inovasi Pendidikan Kimia, 2(2) : 62-65

Wijiayanti, R., Ibnu, S., dan Muntholib., (2017), Hubungan Antara Keterampilan Metakognisi dengan Hasil Belajar Konsep Mol, Jurnal Pembelajaran Kimia, 2(1) : 1-8. 